\title{
The Effect of Jamboree Strategy on Respondents' Knowledge of Prevention of Drug Abuse Before and After Intervention in Junior High School 2 Purba Kinalang, Simalungun Regency
}

\author{
Venni Yuasnita R. Damanik ${ }^{1}$, Kintoko Rochadi ${ }^{2}$ Linda T. $^{2}$ \\ ${ }^{1}$ Master Student in Universitas Sumatera Utara, Medan, Indonesia \\ ${ }^{2}$ Lecturer in Universitas Sumatera Utara, Medan, Indonesia \\ Email: vennidamanik@gmail.com
}

\begin{abstract}
:
This study aims to determine the effect of jamboree strategy on respondents' knowledge of prevention of drug abuse before and after intervention in junior high school 2 Purba Kinalang, Simalungun Regency. The research design that the researchers will do is one group pre-test posttest design which will be conducted in the first week of pre-test and the second week is treated through health education by health workers and the third week will be carried out post-test to determine the effect of health education on treatment groups in increasing adolescent knowledge and attitudes about drugs. The conclusion of this study consists of several points, there were: Frequency distribution of the general characteristics of respondents, the majority of respondents are aged between 12-13 years, as many as $58.1 \%$ and as many as $53.2 \%$ of female (33 people). Knowledge of respondents before being given a jamboree strategy the majority of adolescents were less good at $82.3 \%$. However, after being given a teenage jamboree strategy, the majority of respondents' knowledge was good at $64.5 \%$. Thus there was a change of knowledge after being given the intervention of teenage jamboree.

Keywords:

jamboree strategy; drug abuse; students
\end{abstract}

\section{Introduction}

Adolescence is a phase of development between childhood and adulthood. A person's development in childhood and adolescence will shape the person's self-development in adulthood. At this time, the desire to experiment, to follow trends and lifestyle and to have fun is so great that young people are productive ages who need special attention because at this level the search for identity and tend to be very unstable (Soetjiningsih, 2007: 3). There are various factors that cause or effect a teenager's behavior including friendship, the development of information technology, cultural influences, and hedonic lifestyle. Some of these factors are as triggers in every pattern of one's life as well as in one's mindset including in drug abuse. Friendship factors are the main trigger for teens to try including in drug abuse. This is in line with research conducted by Elviza Rahmadona (2014: 61) that there are several factors that cause adolescents to fall into drug abuse, one of which is a peer influence of negative peers that will negatively influence adolescent behavior can easily carry over to behaviors that are not good like smoking, stealing, and using illegal drugs (vice versa) and vice versa positive peer behavior will affect the behavior of adolescents to be positive as well. According to research conducted by Syarifah and Rahmat Rosyadi (2015) said that the influence of environmental factors and peers is crucial in a person's adolescent behavior patterns. This is reasonable because many adolescents reflect on things that exist outside of themselves and their families, so adolescents depend a lot on environmental factors and their peers.

Life with peers group has a very important meaning for teenagers. Because through interaction in peer groups, adolescents can easily get to know themselves and socialize in an equal 
status. Therefore, adolescents must be properly guided, given proper knowledge through peer groups in teenage jamboree activities. Teenage Jamboree is a movement and activity designed to empower teenagers with the aim of enhancing experience, and education that has a positive impact on the personal growth and development of each child by teaching self-confidence, personal responsibility and character development (Uci-califoria, 2016). In other words, teenage jamboree is a very positive peer group activity in influencing adolescent behavior. Jamboree activities have often been carried out both nationally and internationally with the aim of empowering youth, adolescent mental development. According to Kutim Hj Aisyah (2017) believes that the jamboree is very beneficial for adolescents because in the jamboree activities of adolescents can interact with peer groups and can exchange information so as to create quality teenagers. This research is supported by the opinion of Ulfa Trijayanti (on the Narcotics Drugs Activity) saying that jamboree activities really help teenagers recognize themselves by looking in the mirror from their peers and this activity motivates adolescents to become independent, creative, innovative and achievers.

This Jamboree is a series of activities designed with the aim of increasing personal competence, building character, and increasing social interaction for teenagers. In this activity participants will engage in peer group interaction, learning to face challenges that require individual and group efforts in challenging environments. This activity is also made to help teens overcome feelings of insecurity, helplessness and low self-esteem.

This activity will be carried out for two days in order to make a more effective interaction between individuals and other individuals, between one group and another group. Program participants will be divided into small groups of between 8 and 12 people. They will live together as a new family. For two days they will interact with each other through the activities of playing, discussing, sharing experiences, and working together.

\section{Review of Literature}

\subsection{Behavior}

Based on Skinner's theory, Notoatmodjo (2010) defines behavior as a response or reaction of organisms to stimuli that are reflected in closed and open behavior. This closed behavior is measured through a person's knowledge and attitudes while open behavior can be observed through actions, so in essence the behavior consists of three domains namely knowledge, attitudes and actions.

An educational psychologist, Benjamin Blosom (1908) in Notoatmodjo (2010), distinguishes three behavioral domains namely cognitive, affective, and psychomotor. In further developments in the interest of practical education, the three domains of behavior are developed into knowledge, attitude, and practice.

The concept of Bloom's Taxonomy was developed in 1956 by Benjamin S. Bloom, which was further developed by his student Lorin Anderson in 1990. The results of his improvement were published in 2001 under the name Revised Bloom Taxonomy. One of the reasons why Anderson revised Bloom's Taxonomy was because one of the stages, namely the synthetic and analytical stages, was very difficult to distinguish from one another.

\subsection{Teenagers}

Adolescence is a period marked by physical, emotional and psychological changes. Adolescence at the age of 10-19 years is a period of maturation of the reproduction of human 
organs and is often referred to as puberty. Adolescence is a transition from childhood to adulthood and at this time there is a change in physical organs. Also the process of maturation of sexuality or means of reproduction which is an important part in adolescents' lives, so in this period very special attention from parents is needed (Widyastuti et al, 2009).

Teenagers or often called adolescence, this word comes from the Latin adolescere, which means to grow to reach maturity. (Santrock, 2003) tries to interpret adolescence as a period of developmental transition between childhood and adulthood which includes cognitive, biologic, and social-emotional changes. Although adolescents have very unique characteristics during adolescence, these will be interrelated with the development of experience in childhood and adulthood. This is in line with the understanding of Hurlock (2005), saying further development is the term adolescence has a broader meaning that includes emotional, social, and physical mental maturity.

Early adolescence is a period in which parental conflict with adolescents usually increases from the previous period when still a child. This increase can occur due to several factors which involve adolescence maturity (Santrock, 2003).

According to the World Health Organization (WHO), adolescent criteria can be seen based on biological, psychological and socioeconomic aspects. The most pressing problem is the pregnancy that is too early. Thus to overcome these problems WHO decides or sets an age limit of 10-20 years as the age limit of adolescents. And pregnancy at that age has a higher risk than the age above it (Sarwono, 2005).

\subsection{Drugs}

Drugs stands for narcotics and drugs or dangerous substances. All of these terms, both "drugs", refer to a group of substances that generally have a risk of addiction for their users. Drugs are also often referred to as narcotics, psychotropic substances, and other addictive substances. Etymologically drugs or narcotics come from English narcose or narcosis which means to put to sleep or anesthetize. Narcotics originating from Greek, namely narcotic or narcotic which means anesthetized so that nothing can be felt. In other words narcotics, derived from narcotic words, which means something that can relieve pain and can cause stupor effects (stupidity), anesthetic agents and anesthetics.

\subsection{Teenage Jamboree}

According to Indonesian Dictionary $(\mathrm{KBBI})$, jamboree is a large gathering between groups, regions, cities, nationally, in the form of large encampments. Developed in the world since it was held in 1920 in England. Teenage Jamboree is a movement or strategy designed to empower teenagers with the aim of enhancing experience, and education that has a positive impact on personal growth and development, emotional development of each child by teaching self-confidence, personal responsibility and character development. Through this jamboree, teenage can also exercise independence, broaden their horizons, increase creativity, improve the quality of thinking, and manage emotionally through group interaction.

Life with a group of peers has a very important meaning for teenagers. Through interaction with peer groups, adolescents can get to know themselves in parallel status. Compared to their interactions with parents and teachers, peer groups do not do much criticism so that adolescents feel safe to develop ideas and behaviors (Shaffer, 1988). Thus the teenage jamboree is one of the right methods to collect and assist youth. 
This Jamboree is carried out through several continuous activities namely, activities that involve group interaction with camping for two days. Participants will be divided into small groups of 5-8 members. According to Kimball and Bacon (1993) group interaction activities in the wild are very suitable for adolescents because adolescents prefer activities rather than verbal expressions. Through outdoor camping activities, adolescents will experience group interactions in real life.

\section{Research Method}

This research was conducted using a quantitative approach to the type of quasiexperimental research which aims to determine a symptom that arises as a result of a particular treatment or experiment with pre-test and post-test designs (Hidayat, 2011).

The research design that the researchers will do is one group pre-test post-test design which will be conducted in the first week of pre-test and the second week is treated through health education by health workers and the third week will be carried out post-test to determine the effect of health education on treatment groups in increasing adolescent knowledge and attitudes about drugs.

The design of this research is manifested in the following forms:

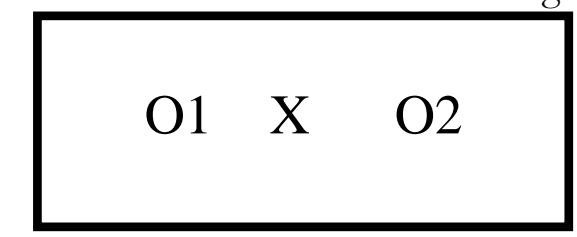

Figure 1. Research design

Information:

a. 01 is the pre-test result of the knowledge's level, attitudes and actions of adolescents in the group that will be treated before the jamboree.

b. $\mathrm{X}$ is the treatment given, namely health education with the jamboree strategy.

c. $\mathrm{O} 2$ is the post-test result of the knowledge's level, attitudes and actions of adolescents after being treated after 1 week.

This research was conducted at Junior High School 2 Purba Kinalang, Purba Sub-district, Simalungun Regency, with the reason based on observations made by researchers in Purba Subdistrict area, it was found that there are teenagers who use drugs, get-together and secretly and in the opinion of researchers this area is very vulnerable for drug use and have never done research on drugs in Junior High School 2 Purba Kinalang.

The number of samples is calculated by the research formula in accordance with Issac and Micheal formulas in Sugiono (2014), namely:

$\mathrm{n}=$

Information:

$\mathrm{n}=$ Sample Size

$\mathrm{N}=$ Population Size (196)

$\mathrm{d}=$ Estimating Error $(0.05)$

$\mathrm{X} 2=$ Chi-Squared $(95 \%=0.95)$

$\mathrm{P}=$ Proportion of Population (0.5) 
Then:

$\mathrm{n}=$

$\mathrm{n}=62.01$ (Rounded to 62 )

Then the number of samples in this study were 62 students.

Validity Test aims to determine the extent of a measure or value that indicates the level of reliability or validity of a measuring instrument by measuring the correlation between variables or items with a total variable score in the reliability analysis by looking at the value of correlation corrected items, with the provisions if the value of $r$ count $>r$ table, then declared valid and vice versa.

Data reliability is an index that shows the extent to which a measuring instrument can continue the accuracy and the data can be trusted using Cronbach's Alpha method, namely analyzing the reliability of measuring devices from one measurement, with the provisions, if the value of $r$ Alpha $>r$ table, then declared reliable (Sugiyono , 2004). The value of $r$ table in this study uses the critical value of the product moment at a significant level of $95 \%$, so for the sample of 10 people tested the r-table value is equal to 0,576 .

The results of testing the validity and reliability showed that all of the research variables were declared valid and reliable, including:

1. Knowledge questions include 10 questions obtained by the value of $t$-count between 0.6555 0,9278 , meaning the value of $\mathrm{t}$-Calculate is greater than $\mathrm{t}$-Table, and the value of $\mathrm{r}$ - $\mathrm{so}$ it is declared valid; and the value of $\mathrm{r}$-count is 0.9617 , it means the value of $\mathrm{r}-\mathrm{h}>\mathrm{r}-\mathrm{t}$, so it is reliably reliable.

2. Attitude questions include 10 questions obtained value $0.6104-0.9737$, meaning the value of $t$ Calculate is greater than $\mathrm{t}$-Table and the value of $\mathrm{r}-\mathrm{so}$ it is declared valid, and the value of $\mathrm{r}$ Calculate is 0.9486 means the value of $\mathrm{r}-\mathrm{h}>\mathrm{r}-\mathrm{t}$, then it is declared reliable.

Knowledge measurement is based on an interval scale based on 10 question items with the correct answer category given a score of 1 , and one given a score of 0 . Then the lowest score obtained 0 and the highest score of 10 According to Arikunto (2010), knowledge is good if the respondent can answer $76-100 \%$ with correct from the total answer to the question. Knowledge is lacking if the respondent can answer $56-75 \%$ of the total answers to the question. In this study, researchers categorized knowledge as good and lacking.

$0=$ Good, if the answer is correct $76-100 \%(7.6-10)$

$1=$ Less, if the correct answer is $\leq 75 \%(\leq 7,5)$

To find out attitudes, the questionnaire uses a Likert Scale by measuring through 10 questions with answer choices strongly agree, agree, disagree and strongly disagree. The provision of assigning value weights to attitude answer items namely (Hidayat, 2010). If the statement is positive, the value weights are:

1. Strongly agree: 4

2. Agree: 3

3. Disagree: 2

4. Strongly disagree: 1

Based on the results of the answers, the attitude assessment is done by taking the average of the scores obtained, namely a score of 10-40.

$0=$ Good, if the answer is correct $76-100 \%(30.4-40)$

$1=$ Less, if the answer is correct $\leq 75 \%(\leq 30)$ 
Measuring actions are based on an interval scale based on 10 question items with the correct answer category given a score of 1 , and one given a score of 0 . Then the lowest score obtained 0 and the highest score of 10 According to Arikunto (2010), good action if the respondent can answer $76-100 \%$ with correct from the total answer to the question. The action is less if the respondent can answer 56-75\% correctly of the total answers to the questions. In this study, researchers categorized actions as good and lacking.

$0=$ Good, if the answer is correct $76-100 \%(7.6-10)$

$1=$ Less, if the correct answer is $\leq 75 \%(\leq 7,5)$

\section{Discussion}

The characteristics of the respondents examined in this study include age and gender in Junior High School 2 Purba Kinalang, Simalungun Regency. The explanation of the characteristics of these respondents can be seen in the following table:

Table 1. Frequency Distribution of Respondent's Characteristics in Junior High School 2 Purba Kinalang, Simalungun Regency

\begin{tabular}{lcc}
\hline \multicolumn{1}{c}{ Characteristics of Respondents } & $\mathbf{n}$ & $\mathbf{\%}$ \\
\hline Age & & \\
$12-13$ years old & 36 & 58,1 \\
14-15 years old & 26 & 41,9 \\
Gender & & \\
Male & 29 & 46,8 \\
Female & 33 & 53,2 \\
\hline Total & 62 & 100 \\
\hline
\end{tabular}

Table 1 shows that the majority of respondents aged between $12-13$ years were $58.1 \%$ and female were $53.2 \%$. Univariate analysis was performed to determine the frequency and percentage of each variable examined in this study. More clearly can be seen in the following sections: An explanation of the categories of good and bad knowledge can be seen in the following table:

Table 2. Knowledge Categories Before and After Being Given Teenage Jamboree Strategy

\begin{tabular}{lccccc}
\hline \multirow{2}{*}{ Knowledge } & \multicolumn{2}{c}{ Before } & $\mathbf{N}$ & After \\
\cline { 2 - 5 } & $\mathbf{n}$ & $\mathbf{0}$ & 40 & 64,5 \\
\hline \multirow{2}{*}{ Good } & 11 & 17,7 & 22 & 35,5 \\
\multicolumn{2}{c}{ Total } & 51 & 82,3 & 62 & 100 \\
\hline
\end{tabular}

Table 2 shows that the majority of respondents' knowledge before being given a teenage Jamboree strategy was not good at $82.3 \%$. However, after being given a teenage jamboree strategy, the majority of respondents' knowledge was good at $64.5 \%$. Knowledge indicators are the results of obtaining information from all questions on the questionnaire before and after the teenage jamboree strategy is given, which can be seen in the following table: 
Table 3. Frequency Distribution of Respondents' Knowledge Answers Before and After Being Given Teenage Jamboree Strategy

\begin{tabular}{|c|c|c|c|c|c|c|c|c|c|}
\hline \multirow{3}{*}{ No. } & \multirow{3}{*}{ Knowledge } & \multicolumn{4}{|c|}{ Before } & \multicolumn{4}{|c|}{ After } \\
\hline & & \multicolumn{2}{|c|}{ Know } & \multicolumn{2}{|c|}{ Didn't Know } & \multicolumn{2}{|c|}{ Know } & \multicolumn{2}{|c|}{ Didn't Know } \\
\hline & & $\mathrm{n}$ & $\%$ & $\mathrm{n}$ & $\%$ & $\mathrm{n}$ & $\%$ & $\mathbf{n}$ & $\%$ \\
\hline 1. & $\begin{array}{l}\text { Do you know about } \\
\text { drugs? }\end{array}$ & 20 & 32,3 & 42 & 67,7 & 49 & 79 & 13 & 21 \\
\hline 2. & $\begin{array}{l}\text { Do you know about } \\
\text { psychotropic? }\end{array}$ & 6 & 9,7 & 56 & 90,3 & 35 & 56,5 & 27 & 43,5 \\
\hline 3. & $\begin{array}{l}\text { Do you know what are } \\
\text { the types of drugs? }\end{array}$ & 29 & 46,8 & 33 & 53,2 & 45 & 72,6 & 17 & 27,4 \\
\hline 4. & $\begin{array}{l}\text { Do you know the dangers } \\
\text { of drug abuse? }\end{array}$ & 19 & 30,6 & 43 & 69,4 & 48 & 77,4 & 14 & 22,6 \\
\hline 5. & $\begin{array}{l}\text { Do you know the dangers } \\
\text { of injecting drug use? }\end{array}$ & 7 & 11,3 & 55 & 88,7 & 32 & 51,6 & 30 & 48,4 \\
\hline 6. & $\begin{array}{l}\text { Do you know what are } \\
\text { the forms of drugs? }\end{array}$ & 9 & 14,5 & 53 & 85,5 & 53 & 85,5 & 9 & 14,5 \\
\hline 7. & $\begin{array}{l}\text { Do you know about the } \\
\text { effects of excessive drug } \\
\text { use? }\end{array}$ & 23 & 37,1 & 39 & 62,9 & 51 & 82,3 & 11 & 17,7 \\
\hline 8. & $\begin{array}{l}\text { Do you know about } \\
\text { alcohol? }\end{array}$ & 19 & 30,6 & 43 & 69,4 & 54 & 87,1 & 8 & 12,9 \\
\hline 9. & $\begin{array}{l}\text { Do you know about the } \\
\text { characteristics of people } \\
\text { who are addicted to } \\
\text { drugs? }\end{array}$ & 10 & 16,1 & 52 & 83,9 & 42 & 67,7 & 20 & 32,3 \\
\hline 10. & $\begin{array}{l}\text { Do you know the } \\
\text { consequences of excessive } \\
\text { alcohol use? }\end{array}$ & 28 & 45,2 & 34 & 54,8 & 45 & 72,6 & 17 & 27,4 \\
\hline
\end{tabular}

Table 3 shows that after the teenage Jamboree strategy was carried out, respondents' knowledge about the definition of drugs and psychotropic, types of drugs, drug abuse, injecting drug use, forms of drugs, effects of drug use, understanding of alcohol, characteristics of people addicted to alcohol, and the result of excessive alcohol use has increased. This means that the intervention of the Jamboree strategy influences the knowledge of adolescents in Junior High School 2 Purba Kinalang, Simalungun Regency.

The statistical test that can be used to determine the effect of teenage jamboree strategies on adolescent knowledge, attitudes, and actions in Junior High School 2 Purba Kinalang, Simalungun Regency is paired samples $t$ test. The following table explains the knowledge of respondents before and after the teenage Jamboree strategy is given.

Table 4. The Effect of Teenage Jamboree Strategy on Teenage Knowledge in Junior High School 2 Purba Kinalang, Simalungun Regency

\begin{tabular}{lccc}
\hline \multicolumn{1}{c}{ Variable } & Mean & SD & P \\
\hline Knowledge & & & \\
Before & 4,42 & 3,038 & 0,000 \\
After & 7,74 & 2,402 & \\
\hline
\end{tabular}

The following table explains the attitudes of respondents before and after the teenagers' jamboree strategies are given. 
Table 5. The Effect of Teenage Jamboree Strategies on Adolescent Attitudes in Junior High School 2 Purba Kinalang, Simalungun Regency

\begin{tabular}{lccc}
\hline \multicolumn{1}{c}{ Variable } & Mean & SD & P \\
\hline Attitude & & & \\
Before & 31,77 & 6,838 & 0,000 \\
After & 37,03 & 3,644 & 0,000 \\
\hline
\end{tabular}

The table shows that the average value of attitude before being given a teenage Jamboree strategy is 31.77 with a standard deviation of 6.838 and the average value of attitude after being given a teenage Jamboree strategy is 37.03 with a standard deviation of 3.644. This means that there is an increase in the average value of attitudes before and after teenage jamboree strategies are given. The table also concludes that there is an influence of teenage Jamboree strategy on attitudes about preventing drug abuse among adolescent Junior High School 2 Purba Kinalang, Simalungun Regency. The following table explains the actions of respondents before and after the teenagers' jamboree strategies are given.

Table 6. The Effect of Teenage Jamboree Strategy on Teenage Actions in Junior High School 2 Purba Kinalang, Simalungun Regency

\begin{tabular}{lccc}
\hline \multicolumn{1}{c}{ Variable } & Mean & SD & P \\
\hline Action & & & \\
Before & 8,03 & 2,127 & 0,000 \\
After & 9,10 & 1,606 & \\
\hline
\end{tabular}

Table 6 shows that the average value of actions before being given a teenage Jamboree strategy is 8.03 with a standard deviation of 2.127 and the average value of actions after being given a teenage Jamboree strategy is 9.10 with a standard deviation of 1.606 . This means that there is an increase in the average value of actions before and after adolescent jamboree strategies are given. This table also explains that there is an influence of teenage jamboree strategies on actions to prevent drug abuse among adolescent Junior High School 2 Purba Kinalang, Simalungun Regency.

Respondents from this study are students who have several characteristics. The characteristics of the respondents examined in this study include age and gender. The respondent group was dominated by adolescents aged $12-13$ years, amounting to 36 people (58.1\%), and the gender was dominated by female each by 33 people $(53.2 \%)$ while male by 29 people $(46,8 \%)$.

Knowledge is the result of knowing and this happens after people have sensed a certain object. Knowledge of respondents about drugs is everything that is known by respondents about the definition of drugs, types of drugs, the effects of drug abuse and efforts to prevent / deal with drugs and the consequences of alcohol abuse.

The results showed that prior to the teenage jamboree there was poor teenage knowledge about drugs, types of drugs and the dangers of drug abuse. The results showed that the majority of respondents' knowledge before being given a teenage Jamboree strategy was not good at $82.3 \%$. But after being given an intervention through teenage jamborees, the majority of respondents' knowledge was good at $64.5 \%$. And the results of the study showed that after intervention, respondents' knowledge about the understanding of drugs and psychotropic drugs, types of drugs, drug abuse, injecting drug use, forms of drugs, the effects of drug use, understanding alcohol, the characteristics of people addicted to alcohol, and as a result of excessive alcohol use has increased. 
This situation conveys information to researchers that intervention teenage jamboree strategy on drugs are very effective in increasing student knowledge related to drugs, this is because adolescent jamborees are not only done in one direction but also carried out participatory interactive and discussion with students. Teenage Jamboree is one of the very important places for adolescents to overcome the complexity of the problems faced. Adolescence is a transitional period between childhood and adulthood, which begins at the time of sexual maturity. Teenagers do not have a clear place, namely that they do not belong to the group of children but do not also belong to the adult group. Biological and psychological development of adolescents is influenced by environmental and social development. Therefore teens will struggle to release their dependence on parents and try to achieve independence so that they can be accepted and recognized as adults (Kumalasari Intan, 2012). So that peer group interaction is the availability of resources that provide physical and psychological comfort for adolescents obtained through adolescent interactions with other adolescents so that individuals feel loved, cared for and valued. Thus adolescent jamboree activities coupled with the media used will help teens be able to interact well. Through this strategy, teenagers can get good information. According to Halloran (1970), giving information through face-to-face contact between the recipient of the message and the party delivering the message enables them to produce changes, both in knowledge, attitudes and actions related to the information provided. In addition, the delivery of messages by peers can change adolescent views strongly. In the opinion of Hendrojuwono (1991), this is caused by peer relations being equal and more pleasant so that adolescents do not feel indoctrinated. Unlike the case if done by parents or teachers, adolescents will feel it as a hierarchical relationship that is task-oriented.

\section{Conclusion}

The conclusion of this study consists of several points, there were: Frequency distribution of the general characteristics of respondents, the majority of respondents are aged between 12-13 years, as many as $58.1 \%$ and as many as $53.2 \%$ of female (33 people). Knowledge of respondents before being given a jamboree strategy the majority of adolescents were less good at $82.3 \%$. However, after being given a teenage jamboree strategy, the majority of respondents' knowledge was good at $64.5 \%$. Thus there was a change of knowledge after being given the intervention of teenage jamboree.

\section{References}

Afandi, D, Fifia, C.Dwi, N, Ivan R.W., Lilik, K. (2009). Tingkat Penyalahgunaan Obat dan Faktor Risiko di Kalangan Siswa Sekolah Menengah Umum, Majalah Kedokteran Indonesia.

Afiatin, Tina. (2008). Pencegahan Penyalahgunaan Narkoba dengan Program AJI. Gadjahmaja University: Yogyakarta.

Ahmadi, A. (1999). Psikologi Sosial, Jakarta: Rineka Cipta.

Alatas, H.H. (2001). Penanggulangan Korban Narkoba : Meningkatkan Peran Keluarga dan Lingkungan. Fakultas Kedokteran, Jakarta: Universitas Indonesia.

Ali, M., dan Asrori, M. (2010), Psikolgi Remaja: Perkembangan Peserta Didik, Bandung: Nuansa

Ali, M., Mohammad A. (2010). Psikologi Remaja: Perkembangan Peserta Didik. Edisi keenam, Jakarta: Media Grafika

Ashery RS, Robertson EB, Kumpfer KL. (1998). Drug Abuse Prevention Through Family Intervention. NIDA Research Monographs.

Aswar, Saifudin. (2005). Sikap Manusia: Teori dan Pengukurannya, Yogyakarta: Pustaka Pelajar.

Azwar, S. (1995). Sikap Manusia, Teori dan Pengukurannya, Yogyakarta: Pustaka Fajar: Bandura, A., 1977. Social Learning Theory, New Jersey : Prentice Hall. Inc. 
Bensley, Robert J. (2008). Pendidikan Kesehatan Masyrakat, Jakarta: Percetakan Kedokteran.

BNN RI. (2016). Ringkasan Ekslklusif Hasil Survei BNN tahun 2016, Jakarta: Survei BNN

BNN RI. (2017). Data Pendukung Press Release Akhir Tahun 2017. Jakarta

Boeree, C.G. (2009). Personalities Theory Personality Theory: A Biosocial Approach. Psychology, Department Shippensburg University

Buletin Kemenkes. (2014). Buletin Jendela dan Data Informasi Kesehatan RI, Kementerian Kesehatan RI, Jakarta.

Choquet., M, Hassler C, Morin D, Fallisard B, Chau N. (2008). Perceived Parenting Styles And Tobacco, Alcohol, And Cannabis Use Among French Adolescents, French: Gender And Family Structure Differential.

Conger, J.J. (1991). Adolescence And Teenage (4th ed), New York: Harper Collins

Creswell, Jhon W. (2017). Research Desaign, Pendekatan Metode Kualitatatif, Kuantitatif, dan Campuran., Yogyakarta: Pustaka Pelajar

Darman, Flavianus. (2006). Mengenali Jenis dan Efek Buruk Narkoba, Jakarta: Visimedia

Effendy, Onong Uchjana. (1995). Ilmu Komunikasi, Teori dan praktek. Bandung: PT. Remaja Rosdakarya

Gunarsa, S.D. (1991). Psikologi Praktis: Anak, Remaja dan Keluarga, Jakarta: BPK Gunung Mulia:

Gunarsa, Singgih D. (2006). Psikologi Perkembangan anak \& Remaja: Jakarta: BPK Gunung Mulia.

Hawari, D. (2003). Penyalahgunaan dan Ketergantungan NAPZA. Jakarta: FKUI

Hikmat, M.M. (2007). Awas Narkoba, Para Remaja Waspada, Jakarta: PT Grafitri Budi

Hurlock, E. (2005). Perkembangan Anak, Jakarta: Erlangga.

Hurlock, Elisabeth. (2005). Psikologi Perkembangan: Jakarta: Erlangga

Husni, H. (2012). Pengaruh Dukungan Orang Tua dan Teman Sebaya terhadap Perkembangan Pemulihan Penyalahgunaan Narkotika Pada Remaja di Panti Sosial Pamardi Putra Insyaf Sumatera Utara. Tesis, Medan: Program Studi S2 Ilmu Kesehatan Masyarakat Fakultas Kesehatan Masyarakat.

Infodatin. (2017). Pusat Data dan Informasi Kementerian Kesehatan RI, Anti Narkoba Sedunia.

James F. McKenzie \& Jan L. Smeltzer. (1997). Planning, Implementing, And Evaluatin Health Promotion Programs A Primer,England: Viocam Company

Kaligis. (2002). Narkoba \& Peradilannya di Indonesia, Bandung: PT Alumni

KPA. (2004). Komisi Penanggulangan Aids: Peraturan Daerah tentang penanggulangan HIV/AIDS, Jakarta: Keputusan Menteri

Lemeshow, S., Hosmer Jr, DW., Klar, J., \& Lwanga, S.K. (1993). Adequacy of Sample Size in Health Studies, England: WHO.

Mappiare, A. (1982). Psikologi Remaja, Surabaya:Usaha Nasional.

Martono. (2000). Pencegahandan Penanggulangan Penyalahgunaan Narkoba Berbasis Sekolah, Jakarta: Balai Pustaka

McMurray, A. (2003). Community Health and Wellness : Socioecological approach.

Monks, F.J. (1999). Psikologi Perkembangan, Yogyakarta: Gajahmada University Pers

NIDA (National Institute on Drug Abuse), (2003). Preventing Drug Use among Children and Adolescents. 2nd Ed.Maryland U.S: Department Healt and Human Sevices - National Institute of Health.

Notoadmodjo S. (2007). Kesehatan Masyrakat, Ilmu dan seni,Jakarta: Rineka Cipta.

Notoadmodjo S. (2012). Promosi Kesehatan dan Prilaku Kesehatan, Jakarta: Rineka Cipta.

Notoadmodjo S. (2002).Ilmu Prilaku Kesehatan. Jakarta:Rineka Cipta.

Notoatmodjo, S. (2003). Pendidikan dan Perilaku Kesehatan,Jakarta: Rineka Cipta.

Nuryoto., Kemandirian Remaja Ditinjau dari Tahap Perkembangan Jenis Kelamin.

Papalia, D E., Olds, S. W., \& Feldman, Ruth D. (2001). Human development (8th ed.), McGraw- 
Hill: Boston.

Partodiharjo S. (2007). Kenali Narkoba dan Musuhi Penyalahgunaanya, Jakarta: Esensi.

PIMANSU. (2014). Pusat Informasi Masyarakat Anti Narkoba Sumatera Utara, Medan.

Priyoto. (2014). Teori Sikap \& Perilaku dalam Kesehatan,Yogyakarta: Nuha Medika.

Rakhmat, Jalaluddin. (1994). Psikologi Komunikasi, Bandung: Remaja Rosdakarya.

Santjaka, Aris. (2015). Aplikasi SPSS untuk Analisis Data Penelitian Kesehatan, Yogyakarta: Nuha Medika.

Santosa, Slamet. (1992). Dinamika Kelompok,Jakarta: PT. Bumi Aksara.

Santrock, J.W, (2003). Adolescence Perkembangan Remaja, Alih bahasa :Sinto B, Adelar, Sherly Saragih, Jakarta: Erlangga

Sarwono, W.S. (2005). Psikologi Remaja, Jakarta: Raja Grafindo.

Sasangka H. (2003). Narkotika dan Psikotropika dalam Hukum Pidana, Bandung: Mandar Maju

Sear, O. David., Freedman, Jonathan, L. \& Peplau, L. Anne. (1985). Psikologi Sosial Edisi Kelima Jilid I,Jakarta : Erlangga.

Shaffer, David R.. (1988), Developmental Psychology: Child hood and Adolessence,

Siswanto, Suryono., (2001). Penanggulangan Bahaya Narkoba: Media Informasi dan Edukasi Penyalahgunaan Narkoba, Jakarta: Visimedia.

Subaris, Heru. (2016). Promosi Kesehatan, Pemberdayaan Masyarakat, dan Modal Sosial, Nuha Medika: Yogyakarta

Sugiyono. (2016). Metode Penelitian Kombinasi (Mixed Methods), Bandung: Alphabeta.

Sunarso, Siswanto., (2004). Penegakan Hukum Psikotropika dalam Kajian Sosiologi Hukum, Jakarta Utara: PT Raja Grafindo.

Syah, Muhibbi. (2010). Psikologi Pendidikan, Jakarta: Rosda

Sthepani, Markus,( 2004). Manajemen Bisnis, Rineka Cipta, Jakarta, hlm. 338-389

Tim Redaksi, (2012). Perundangan Narkotika. Pustaka Yustisia,Yogyakarta.

Toronto : Mosby Nevid, J.S., Rathus, S.A., \& Greene, B. (2005). Psikologi Abnormal Edisi Kelima Jilid 1. Terjemahan: Tim Fakultas Psikologi Universitas Indonesia. Jakarta:Erlangga

UNODC. (2013). Annual Progress Report, Austria

UNODC. (2014). World Drug Report.Jakarta

Wahid, Abdul. (2006). Psikologi Pendidikan, Jakarta: Rineka Cipta.

Widyastuti, Yani. (2009). Kesehatan Reproduksi, Yogyakarta: Fitramaya

Winkel, W.S. (1987). Psikologi Pengajaran, Jakarta: Gramedia 